BOTANICA

ISSN 2538-8657

2020, 26(1): 76-87

\title{
COMPARATIVE EVALUATION OF ARGANIA SPINOSA AND OLEA EUROPAEA LEAF PHENOLIC COMPOUNDS AND THEIR ANTIOXIDANT ACTIVITY
}

\author{
Aziza Lfitat*, Hind ZeJli, Abdelkamel Bousselham, Yassine El AtKI, Badiaa Lyoussi, \\ Abdelkader Gourch, Abdelfattah Abdellaoui
}

Sidi Mohamed Ben Abdellah University, Faculty of Sciences Dhar El Mahraz, Department of Biology, B. P. 1796 Fes-Atlas, Morocco

*Corresponding author. E-mail: 1fitat.aziza@gmail.com

\begin{abstract}
Lfitat A., Zejli H., Bousselham A., El Atki Y., Lyoussi B., Gourch A., Abdellaoui A., 2020: Comparative evaluation of Argania spinosa and Olea europaea leaf phenolic compounds and their antioxidant activity. Botanica, 26(1): 76-87.

We conducted this study to determine and compare the content of phenolic compounds and flavonoids in the argan and olive leaves as well as their antioxidant capacity in aqueous, methanolic, and ethyl acetate extracted fractions. In vitro antioxidant activity was evaluated in comparison with synthetic antioxidants by assessing $\mathrm{DPPH}^{*}$ radical scavenging capacity, ferric reducing antioxidant power, scavenging ability by inhibiting the $\beta$-carotene/linoleic acid emulsion oxidation, and by the ABTS radical scavenging activity assay. Total phenolic content in argan samples ranged from $221.69 \pm 2.07$ to $1.32 \pm 0.01 \mathrm{mg} \mathrm{GAE} / \mathrm{g}$ DW and in olive samples from $144.61 \pm 0.82$ to $1.21 \pm 0.02 \mathrm{mg} \mathrm{GAE} / \mathrm{g} \mathrm{DW}$. Total flavonoids content in argan samples varied from $267.37 \pm$ 1.12 to $25.48 \pm 0.02 \mathrm{mg} \mathrm{QE} / \mathrm{g} \mathrm{DW}$, while in olives from $96.06 \pm 0.78$ to $10.63 \pm 0.05 \mathrm{mg} \mathrm{QE} / \mathrm{g} \mathrm{DW}$. In vitro antioxidant studies strongly confirmed the antioxidant potency of argan and olive leaves and their richness in secondary metabolites that are effective in free radicals scavenging and metal chelating capacities, indicating their antioxidant power.
\end{abstract}

Keywords: antioxidant activity, Argania spinosa, flavonoids, Olea europaea, phenolic compounds, radical scavenging.

\section{INTRODUCTION}

During the past decades, it became apparent that reactive oxygen species (ROS) and reactive nitrogen species (RNS), collectively termed RONS (WOOTTON-BEARD \& RYAN, 2011), exert a multitude of biological effects. They are covering a broad spectrum that ranges from physiological regulatory functions to damaging alterations participating in the pathogenesis of an increasing number of diseases (ALFADDA \& SALLAM, 2012). Free radicals and RONS are metabolic products continuously generated from various cells in the human body, and they are fundamental to many biochemical processes. They represent an essential part of aerobic life produced as an effect of oxidative metabolism and mediated oxidative damage to macromolecules namely lipids, proteins, DNA, and, thus, result in the incidence of severe illnesses (ATHAR, 2002). To maintain a state of homeostasis, living organisms are striving to keep those highly reactive molecules under tight control with the help of an intricate system of antioxidants (WoOtTon-Beard \& Ryan, 2011). For that, plant natural antioxidants have been investigated due to their safety and efficiency (SHI et al., 2019).

The Mediterranean flora exhibits broad biodiversity, including a notably high number of native aromatic and medicinal plants, many of which may have several pharmacological potencies (TAIR et al., 2014). Argania spinosa (L.) Skeels is the only repre- 
sentative of the Amphi-Atlantic tropical/subtropical Sapotaceae family in northwestern Africa (PENNINGTON, 1991). It is a shrubby threatened plant, endemic and grows mainly in the arid and semiarid southwestern part of Morocco, plays a vital environmental and socioeconomic role. Its conservation is a significant stake for the country. The oil prepared from its fruit is the best-known product of the tree; the fruits and foliage are mainly used in the feeding of herds (CHARRouf \& Guillaume, 2007), especially goats with a diet contribution proportion of 35 to $68 \%$ (EL Aich et al., 2007). As a positive benefit, the residents emphasise good sensory quality (colour, juiciness, taste) and healthiness of the herd meat that depends on argan leaves and fruits in their feeding diet.

Olea europaea L. is distributed mainly in the Mediterranean basin since ancient times, and its cultivated forms have been introduced into many areas (BESNARD et al., 2007). The most well-known use of the olive tree is undoubtedly the production of the oil used for food, cosmetic and therapeutic purposes (Bisignano et al., 1999). Additionally, its medicinal properties are attributed to their leaves which are primarily used as animal feed (SoulLEM et al., 2017) and latterly as a valuable source of energy biomass and bioactive compounds (SPINELli \& Picch, 2010; GULLÓN et al., 2018).

In recent years, significant attention was attracted to some plant leaves regarding their bioactive molecules. Likewise, argan and olive leaves have been themes of several studies. However, to our knowledge, these works have never been the subject of comparative studies between argan and olive leaves under the same experimental conditions (DJIDEL et al., 2014; KHAliQ et al., 2015; DAKICHE et al., 2016; Çetinkaya \& Kulak, 2016). This study for the first time presented a comparative evaluation of the antioxidant potency level of different argan and olive leave fractions, potentially rich in bioactive molecules and precursors of antioxidant nature necessarily used for plant protection and during the process of the fruit fatty acid synthesis.

\section{MATERIALS AND METHODS}

\section{Reagents and standards}

The chemicals 2,2-diphenyl picrylhydrazyl (DPPH), ABTS (2,2'-azino bis (3-ethylbenzothia- zoline-6-sulfonic acid)), butylated hydroxytoluene (BHT), Trolox (6-hydroxy-2,5,7,8-tetramethylchroman-2-carboxylic acid), ammonium molybdate, sodium phosphate, sulfuric acid, gallic acid, $\mathrm{FeCl}_{3}$, $\mathrm{K}_{3} \mathrm{Fe}(\mathrm{CN})_{6}$, and Folin-Ciocalteu reagents were purchased from Sigma-Aldrich (St. Louis, MO, US). All the other chemicals and solvents used were of analytical grade. The absorbance was measured with a spectrophotometer (Model Jasco V-530).

\section{Plant material and extraction}

Argan (Argania spinosa (L.) Skeels var. apiculata) and olive (Olea europaea (L) var. moroccan picholine) leaves were collected in April 2018, from Agadir $\left(30^{\circ} 26^{\prime} \mathrm{N}, 9^{\circ} 36^{\prime} \mathrm{W}\right)$ and Sefrou (33 $43^{\prime} 45.68^{\prime \prime}$ $\left.\mathrm{N}, 4^{\circ} 50^{\prime} 22.12^{\prime \prime} \mathrm{W}\right)$ regions, respectively. The leaves were dried for two weeks at ambient temperature and crushed in an electric blender. The leaf extracts were obtained by Soxhlet apparatus fractionated extraction, using $50 \mathrm{ml}$ of solvent as distilled water, methanol or ethyl acetate, and $3 \mathrm{~g}$ of argan or olive leaf powder (the quantity that was conserved during the process of extraction). The Soxhlet extraction lasted for 16 hours, each time we used a new type of solvent for the total depletion of the plant material. The use of different solvents provided three different fractions of leaf extracts that were refrigerated in an airtight bottle protected from light and oxygen until analysis.

\section{Yield}

The yield of raw material extraction was defined as the ratio between the mass of the dry extract obtained and the mass of the treated plant material. First, we calculated the mass in grams of the dry extract resulting from the dryness of one $\mathrm{ml}$ of the leaf extract (M1), using a glass dish and the oven for evaporation:

$M_{1}=D_{1}-D_{0}$, where $M_{1}-$ mass in grams of the dry extract resulting from the dryness of one millilitre of leaf extract obtained; $\mathrm{D}_{0}-$ mass in grams of the empty glass dish; $\mathrm{D}_{1}$ - mass in grams of the glass dish that was filled with $1 \mathrm{ml}$ of leaf extract and that the solvent was removed.

The extraction yield was calculated by the following formula:

$\mathrm{Y}=\left(\mathrm{M}_{1} \times 50\right) / \mathrm{M}_{0} * 100$, where $\mathrm{Y}-$ yield expressed as a percentage; $M_{0}$ - mass in grams of the plant material initially treated. 


\section{Total phenolic content}

Total phenolic content (TPC) was determined colourimetrically by the Folin-Ciocalteu method (Slinkard \& Singleton, 2010). Briefly, $0.5 \mathrm{ml}$ of known dilution of the extract and $2 \mathrm{ml}$ of $7 \%$ sodium carbonate solution were added to $2.5 \mathrm{ml}$ of $10 \%(\mathrm{v} / \mathrm{v})$ Folin-Ciocalteu reagent. The absorbance was read at $760 \mathrm{~nm}$ after $2 \mathrm{~h}$ of reaction at room temperature in the dark. Gallic acid was used as a standard for the construction of the calibration curve. Total phenolic content was expressed as milligrams of gallic acid equivalents per gram dry weight (mg GAE/g DW).

\section{Total flavonoid content}

Total flavonoid content (TFC) was determined spectrophotometrically using the procedure described by DJERIDANE et al. (2006) that is based on the formation of a flavonoid-aluminum complex. The sample of $1.5 \mathrm{ml}$ was mixed with $1.5 \mathrm{ml}$ of $2 \%$ aluminum chloride $\left(\mathrm{AlCl}_{3}\right)$ solution. After incubation at room temperature for $30 \mathrm{~min}$, the mixture absorbance was measured against the blank at $430 \mathrm{~nm}$. Quercetin was used as a standard for the construction of the calibration curve, and the total flavonoid content was expressed as mg quercetin equivalents per gram dry weight (mg QE/g DW).

\section{Antioxidant activity}

\section{Scavenging ability on DPPH radical}

The antioxidant potential of the extracts was determined based on their scavenging activity of the stable 1,1-diphenyl-2-picrylhydrazyl (DPPH) free radical, and it was measured after the BURITS \& BUCAR (2000) method. Briefly, $0.1 \mathrm{ml}$ of various concentrations of the extract or standard antioxidant was added to $0.75 \mathrm{ml}$ of methanolic solution of DPPH $(0.004 \%)$ and $0.65 \mathrm{ml}$ of methanol. The mixture was shaken vigorously and placed in the dark at room temperature. The absorbance was measured at $517 \mathrm{~nm}$ after 30 min of incubation time. The synthetic antioxidant BHT served as a positive control, and the inhibition percentage was calculated using the following equation:

DPPH scavenging capacity $(\%)=\left[\left(\mathrm{A}_{0}-\mathrm{A}_{1}\right) / \mathrm{A}_{0}\right]$ * 100, where $\mathrm{A}_{0}$ is the absorbance of the control at 30 min and $A_{1}$ is the absorbance of the sample at $30 \mathrm{~min}$.
The concentrations providing $50 \%$ of initial free radicals inhibition $\left(\mathrm{IC}_{50}\right)$ were calculated from the graph of inhibition percentage.

\section{Ferric reducing antioxidant power}

Ferric reducing antioxidant power (FRAP) assay measures the electron-donating ability of antioxidants using the potassium ferricyanide reduction method. Antioxidants reduce the ferric iron/ferricyanide complex to the ferrous form. It was assessed according to the OyAIZU (1986) method, whereby, various concentrations of extracts $(2.5 \mathrm{ml})$ were mixed with $2.5 \mathrm{ml}$ of phosphate buffer $(0.2 \mathrm{M}, \mathrm{pH} 6,6)$ and $2.5 \mathrm{ml}$ of $1 \%$ potassium ferricyanide $\left(\mathrm{K}_{3} \mathrm{Fe}[\mathrm{CN}]_{6}\right)$. This mixture was incubated at $50^{\circ} \mathrm{C}$ for $20 \mathrm{~min}$, and then, $2.5 \mathrm{ml}$ of $10 \%$ trichloroacetic was added, and the mixture was centrifuged at $3000 \mathrm{rpm}$ for $10 \mathrm{~min}$. The upper layer fraction $(2.5 \mathrm{ml})$ was mixed with $2.5 \mathrm{ml}$ of distilled water and $100 \mu 1$ of $0.1 \%$ ferric chloride $\left(\mathrm{FeCl}_{3}\right)$. The absorbance was measured at $700 \mathrm{~nm}$, and quercetin was used as a positive control. Higher absorbance indicated higher reducing power, and the results were expressed as $\mathrm{IC}_{50}(\mathrm{mg} / \mathrm{ml})$, which was the effective concentration corresponding to 0.5 of absorbance.

\section{Total antioxidant capacity}

The total antioxidant capacity (TAC) test is based on the reduction of Mo (VI) to Mo (V) and subsequent formation of a green phosphate/Mo (V) complex at acid pH (Prieto et al., 1999). A total volume of $25 \mu \mathrm{l}$ of the extract or standard antioxidant at various concentrations was added to $1 \mathrm{ml}$ of reagent solution ( $0.6 \mathrm{M}$ sulfuric acid, $28 \mathrm{mM}$ sodium phosphate and $4 \mathrm{mM}$ ammonium molybdate). The closed tubes were incubated in a thermal block at $95^{\circ} \mathrm{C}$ for $90 \mathrm{~min}$ and then cooled to room temperature. The absorbance was measured at $695 \mathrm{~nm}$ against a blank, and ascorbic acid was used as a positive control. The antioxidant activity was expressed as mg ascorbic acid equivalents per gram of dry weight (mg AAE/g DW).

\section{$\beta$-Carotene bleaching assay}

The $\beta$-carotene bleaching inhibition test was performed as described by Ozsoy et al. (2008) with a slight modification. This method was carried out to estimate the capacity to inhibit the $\beta$-carotene bleaching using a $\beta$-carotene/linoleic acid model. We 
transferred $10 \mu \mathrm{l}$ of linoleic acid and $100 \mu \mathrm{l}$ of Tween 80 into a flask, and then added $1 \mathrm{ml}$ of $\beta$-carotene solution ( $2 \mathrm{mg}$ of $\beta$-carotene powder dissolved in $10 \mathrm{ml}$ of chloroform). After that, the chloroform was removed by using rotary evaporation at $40^{\circ} \mathrm{C}$. To the residue, $25 \mathrm{ml}$ of $30 \%$ hydrogen peroxide was added slowly, and the solution was vigorously shaken to form a stable emulsion. To $2.5 \mathrm{ml}$ of this prepared emulsion we added $100 \mu \mathrm{l}$ of diluted extract or reference antioxidant (ascorbic acid) at a concentration of $35 \mathrm{mg} / \mathrm{ml}$. A negative control was carried out in parallel, comprising $2.5 \mathrm{ml}$ of the $\beta$-carotene emulsion and $100 \mu \mathrm{l}$ of methanol. The mixture was well stirred, and the reading of the absorbance was immediately $\left(\mathrm{t}_{0}\right)$ at $470 \mathrm{~nm}$ against a blank test consisting of the emulsion without beta-carotene. The covered test tubes were placed in a water bath set at $50^{\circ} \mathrm{C}$, and the reading of the absorbance was made at different time intervals $(0 \mathrm{~min}, 60 \mathrm{~min}, 90 \mathrm{~min}, 120 \mathrm{~min}$, $150 \mathrm{~min}$ and $180 \mathrm{~min}$ ) and by keeping the sample tubes in the water bath until the visual disappearance of $\beta$-carotene in the control sample (about $180 \mathrm{~min}$ ). The bleaching rate of the $\beta$-carotene solution was determined by measuring the difference between initial reading in spectral absorbance at time $0 \mathrm{~min}$ and after $180 \mathrm{~min}$. Samples antioxidant activity was evaluated in terms of bleaching inhibition of $\beta$-carotene using the formula:

$\mathrm{AA}=\%$ inhibition $\left.=\left[1-\left(\mathrm{As}_{0}-\mathrm{As}\right) / \mathrm{Ac}_{0}-\mathrm{Ac}\right)\right]$ *100, where $\mathrm{As}_{0}$ and As were the absorbance values measured at zero time of the incubation for test sample and control, respectively. $\mathrm{Ac}_{0}$ and $\mathrm{Ac}$ were the absorbance measured in the test sample and control, respectively, after incubation for $180 \mathrm{~min}$.

\section{ABTS radical scavenging activity}

The assay of $\mathrm{ABTS}^{+}$radical scavenging activity was performed using the method of Re et al. (1999) with a slight modification. The cationic radical $\mathrm{ABTS}^{+}$was obtained by the reaction between $10 \mathrm{ml}$ of $2 \mathrm{mM}$ ABTS (diammonium salt) and $100 \mu \mathrm{l}$ of potassium persulfate $\mathrm{K}_{2} \mathrm{~S}_{2} \mathrm{O}_{8}$ at $70 \mathrm{mM}$. The mixture was incubated in the dark for 24 hours at room temperature before use. The $\mathrm{ABTS}^{+}$solution obtained was diluted with methanol to obtain an absorbance between 0.7 and 0.8 at $734 \mathrm{~nm}$. We mixed $2850 \mu 1$ of generated $\mathrm{ABTS}^{+}$solution with $150 \mu \mathrm{l}$ of extract or used a standard Trolox as a positive control. The absorbance values were measured at $734 \mathrm{~nm}$ against a blank after 30 min of incubation in the dark. Antiradical power of the extract was expressed as the inhibition percentage of the radical $\mathrm{ABTS}^{+}$according to the following formula:

$\mathrm{ABTS}^{+}$radical scavenging activity $(\%)=[\mathrm{As}-$ $\mathrm{Ac}] / \mathrm{Ac} * 100$, where As is the absorbance of the sample at $\mathrm{t}=30 \mathrm{~min}$ and $\mathrm{Ac}$ is the absorbance of the control at $\mathrm{t}=30 \mathrm{~min}$. The $\mathrm{IC}_{50}$ values were calculated as the concentrations providing $50 \%$ of initial $\mathrm{ABTS}^{+}$ radical inhibition.

\section{Statistical analysis}

Statistical analysis was carried out by one-way analysis of variance (ANOVA) test using a statistical package programme (GraphPad Prism 5.03), and the significance of the difference between means was determined by Duncan's multiple range test at $(p<0.05)$ significant level. Pearson's correlation (r) was carried to determine whether there was a statistically significant positive or negative relationship between the phenolic compounds and antioxidant activities. Assays were performed in triplicate, and the results were shown as mean \pm SD.

\section{RESULTS}

\section{Yield, total phenolic and flavonoid contents}

The extraction yield of argan and olive leaves varied under the solvent used (Table 1). The yield of argan leaf extracts decreased depending on the solvent in the following order: aqueous $>$ methanolic $>$ ethyl acetate. Meanwhile, the yield of olive leaf extracts descended from methanolic to ethyl acetate extractions. According to Myasnikov et al. (2010), the discrepancy in the extraction yield is highly dependent on the kinetic process: temperature, pressure, and solvent polarity during plant material extraction.

In general, the aqueous and methanolic leaf fractions showed higher values of phenolic and flavonoid contents than the ethyl acetate fractions (Table 1). Quantitative analysis showed that the total phenolic content in aqueous fractions was higher than in methanolic ones. Conversely, the rate of flavonoids in the methanolic extracts was greater than in aqueous samples. Total phenolic compounds were estimated by the use of the standard curve equation of gallic acid equivalent: $\mathrm{y}=11.554 \times\left(\mathrm{r}^{2}=0.9934, p<0.05\right)$. The high- 
Table 1. The extraction yield, total phenolic and flavonoid contents in aqueous, methanolic and ethyl acetate extracts of argan and olive leaves

\begin{tabular}{|l|c|c|c|c|c|c|}
\hline \multirow{2}{*}{ Sample } & \multicolumn{2}{|c|}{ Yield $(\mathrm{w} / \mathrm{w}) \%$} & \multicolumn{2}{c|}{ Total phenolic content $\mathrm{t}^{\mathrm{1}}$} & \multicolumn{2}{c|}{ Total flavonoid content $^{\mathbf{2}}$} \\
\cline { 2 - 7 } & Argan & Olive & Argan & Olive & Argan & Olive \\
\hline AQ & 50.91 & 33.93 & $221.69 \pm 2.07^{\mathrm{a}}$ & $144.61 \pm 0.82^{\mathrm{a}}$ & $123.12 \pm 0.49^{\mathrm{b}}$ & $83.23 \pm 0.21^{\mathrm{b}}$ \\
\hline ME & 24.17 & 46.01 & $210.93 \pm 1.24^{\mathrm{b}}$ & $60.08 \pm 0.31^{\mathrm{b}}$ & $267.37 \pm 1.12^{\mathrm{a}}$ & $96.06 \pm 0.78^{\mathrm{a}}$ \\
\hline EA & 6.26 & 5.75 & $1.32 \pm 0.01^{\mathrm{c}}$ & $1.21 \pm 0.02^{\mathrm{c}}$ & $25.48 \pm 0.02^{\mathrm{c}}$ & $10.63 \pm 0.05^{\mathrm{c}}$ \\
\hline
\end{tabular}

Results represent mean $\pm \mathrm{SD}(\mathrm{n}=3)$. AQ - aqueous, ME - methanolic, EA - ethyl acetate, ${ }^{1}-\mathrm{mg}$ GAE $/ \mathrm{g} \mathrm{DW}(\mathrm{mg}$ gallic acid equivalents /g dry weight), ${ }^{2}-\mathrm{mg} \mathrm{QE} / \mathrm{g} \mathrm{DW}$ (mg quercetin equivalents /g dry weight). Mean values followed by different superscript in a column are significantly different $(p<0.05)$.

est values of phenolics were detected in aqueous and methanolic argan fractions with the content of 221.69 \pm 2.07 and $210.93 \pm 1.24 \mathrm{mg} \mathrm{GAE} / \mathrm{g} \mathrm{DW}$, respectively. In olive fractions total phenolics composed 144.61 \pm 0.82 and $60.08 \pm 0.31 \mathrm{mg} \mathrm{GAE} / \mathrm{g} \mathrm{DW}$, respectively. On the other hand, flavonoids content exceeded in methanolic and aqueous argan fractions (267.37 \pm 1.12 and $123.12 \pm 0.49 \mathrm{mg}$ QE/g DW, respectively) compared to the corresponding fractions of olive leaves $(96.06 \pm 0.78$ and $83.23 \pm 0.21 \mathrm{mg} \mathrm{QE} / \mathrm{g} \mathrm{DW})$. Flavonoid content was calculated in terms of quercetin equivalent using a standard curve equation: $\mathrm{y}=6.0423$ $\mathrm{x}+0.065\left(\mathrm{r}^{2}=0.99, p<0.05\right)$. The total flavonoid concentrations in ethyl acetate fractions of argan and olive leaves $(25.48 \pm 0.02$ and $10.63 \pm 0.05 \mathrm{mg} \mathrm{QE} / \mathrm{g}$ $\mathrm{DW}$, respectively) were estimated higher compared to the total phenolic contents $(1.32 \pm 0.01$ and $1.21 \pm$ $0.02 \mathrm{mg}$ QE/g DW, respectively) (Table 1).

\section{Reducing antioxidant power and radical scaven- ging activities}

In vitro antioxidant activities, expressed as fractional concentrations providing 50\% inhibition, are presented in Table 2. The lowest $\mathrm{IC}_{50}$ value expressed the highest antioxidant activity. The ferric reducing antioxidant power activity of the studied leaves varied significantly from 0.420 to $1.880 \mathrm{mg} / \mathrm{ml}(p<0.05)$. The most effective antioxidant power activities were detected in methanolic and aqueous fractions of argan and olive leaves $(0.420 \pm 0.001$ and 1.018 $\pm 0.004 \mathrm{mg} / \mathrm{ml}$, respectively). Methanolic olive and aqueous argan extracts reached the medium of inhibition at $1.380 \pm 0.002$ and $1.647 \pm 0.007 \mathrm{mg} / \mathrm{ml}$, respectively. The lowest reducing ability was detected for ethyl acetate fractions of olive $(1.720 \pm 0.001 \mathrm{mg} /$ $\mathrm{ml})$ and $\operatorname{argan}(1.880 \pm 0.003 \mathrm{mg} / \mathrm{ml})$. In addition, all samples tested were estimated to have lower antioxidant activity compared to quercetin used as a positive

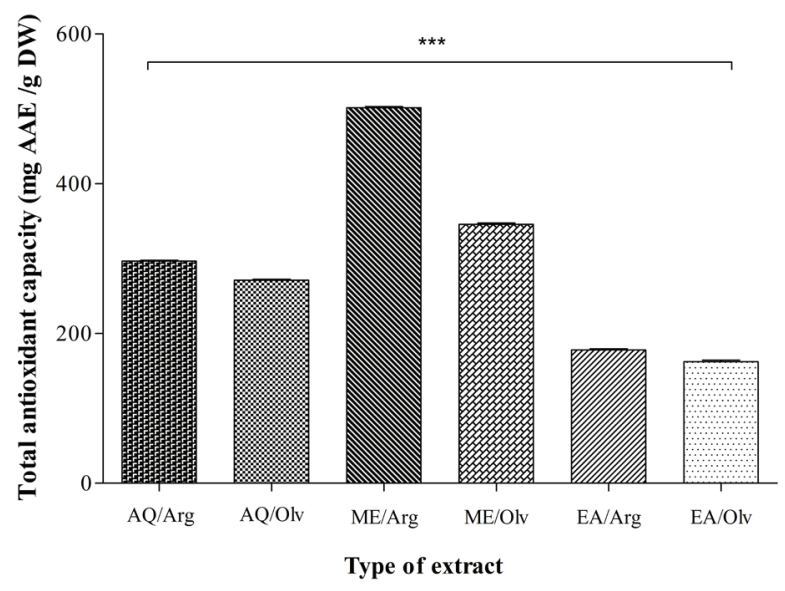

Fig. 1. Total antioxidant capacity of different argan and olive leaves fractions expressed as mg AAE /g DW (mg ascorbic acid equivalents /g dry weight). AQ - aqueous, ME - methanolic, EA - ethyl acetate, Arg - argan, Olv - olive. Each column value represents the mean $\pm \mathrm{SD}$ of three samples $(* * *$ significant at $p<0.05$ )

control $\left(\mathrm{IC}_{50}=0.033 \pm 0.006 \mathrm{mg} / \mathrm{ml} ; \mathrm{y}=0.0135 \mathrm{x}+\right.$ $\left.0.0354 ; \mathrm{r}^{2}=0.9946, p<0.05\right)$.

Considering all 50\% inhibition concentrations obtained by DPPH assay, the methanolic argan fraction showed the greatest antioxidant efficacy $\left(\mathrm{IC}_{50}\right.$ $=0.212 \pm 0.001 \mathrm{mg} / \mathrm{ml}$ ), followed by the aqueous and ethyl acetate argan fractions $\left(\mathrm{IC}_{50}=0.823 \pm\right.$ $0.004 \mathrm{mg} / \mathrm{ml}$ and $0.940 \pm 0.003 \mathrm{mg} / \mathrm{ml}$, respectively) (Table 2). Meanwhile, the $\mathrm{IC}_{50}$ values of the methanolic, aqueous and ethyl-acetate olive leave fractions showed a decrease in antioxidant activity, expressed as an increase in the inhibitory concentration $(1.380 \pm 0.005 ; 1.643 \pm 0.014$ and $1.725 \pm 0.021 \mathrm{mg} /$ $\mathrm{ml}$, respectively). Antioxidant activity of argan leaf extracts showed the same trend as olive extracts and was lower compared to the BHT used as a positive equivalent control $\left(\mathrm{IC}_{50}=0.110 \pm 0.002 \mathrm{mg} / \mathrm{ml}\right)$.

Regarding the ABTS assay, the results were varying and higher antioxidant activity was observed 
compared to all aqueous argan fraction (Table 2). The aqueous argan extract showed higher scavenging activity against the $\mathrm{ABTS}^{+}$radical than the aqueous olive extract $\left(\mathrm{IC}_{50}=1.380 \pm 0.013\right.$ and $3.342 \pm 0.006$ $\mathrm{mg} / \mathrm{ml}$, respectively). Contrary, methanolic olive fraction expressed a stronger activity than the methanolic argan fraction $\left(\mathrm{IC}_{50}=1.647 \pm 0.004 \mathrm{mg} / \mathrm{ml}\right.$ and $\mathrm{IC}_{50}=$ $2.120 \pm 0.002 \mathrm{mg} / \mathrm{ml}$, respectively). Using ABTS assay, ethyl acetate fractions were ineffective in radical scavenging and were expressed as undetectable results. All the examined samples were estimated to hold lower antioxidant activity compared to Trolox, with an $\mathrm{IC}_{50}$ value of $0.126 \pm 0.005 \mathrm{mg} / \mathrm{ml}$. Otherwise, the ABTS assay provided significantly higher antioxidant activity than using the DPPH method. We can explain that by the fact that lower stability was associated with higher reactivity of $\mathrm{ABTS}^{+}$radicals compared to $\mathrm{DPPH}^{*}$ radicals.

\section{Total antioxidant capacity}

Total antioxidant capacity (TAC) assay estimated both water-soluble and fat-soluble antioxidants (PRIETO, 1999). TAC values were detected by using standard curve equation equivalent to ascorbic acid: $\mathrm{y}=1.517 \mathrm{x}-$ $0.0564\left(\mathrm{r}^{2}=0.9955, p<0.05\right)$. Argan and olive methanolic fractions exposed the highest antioxidant potential compared to the rest of fractions. TAC obtained in the methanolic argan fraction was the highest (501.5 \pm $2.97 \mathrm{mg} \mathrm{AAE} / \mathrm{g} \mathrm{DW})$, and then decreased in the following fractions: methanolic olive $(345.7 \pm 3.57 \mathrm{mg}$ AAE $/ \mathrm{g}$ DW), aqueous argan $(296.7 \pm 2.05 \mathrm{mg} \mathrm{AAE} / \mathrm{g} \mathrm{DW})$, aqueous olive (271.2 $\pm 1.97 \mathrm{mg} \mathrm{AAE} / \mathrm{g} \mathrm{DW})$, ethyl acetate argan $(178.1 \pm 2.29 \mathrm{mg} \mathrm{AAE} / \mathrm{g} \mathrm{DW})$ and the ethyl acetate olive (162.2 $\pm 3.84 \mathrm{mg} \mathrm{AAE} / \mathrm{g} \mathrm{DW})$.

\section{$\beta$-carotene bleaching assay}

The measure of the $\beta$-carotene bleaching inhibition was determined based on the ability of the studied fractions to reduce hydroperoxides as free radicals generated in a linoleic acid system via betacarotene bleaching assay (Ozsoy et al., 2008). As shown in Fig. 2 , the highest percentage of $\beta$-carotene bleaching inhibition was found in methanolic argan (83.96\%) and olive (68.41\%) leaf fractions followed

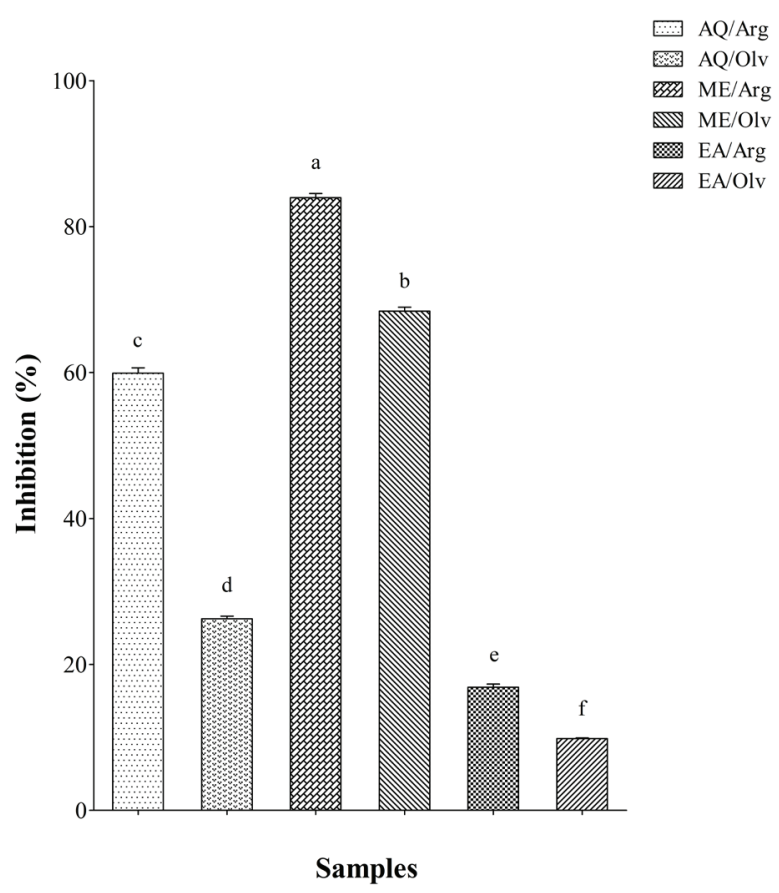

Fig. 2. Percentage of $\beta$-carotene bleaching inhibition (I \%) in different argan and olive extracted fractions. Each column value represents the mean $\pm \mathrm{SD}$ of three samples. $\mathrm{AQ}$ - aqueous, ME - methanolic, EA - ethyl acetate, Arg - argan, Olv olive. Vertical bars labelled with different letters are significantly different at $p<0.05$

Table 2. Inhibitory potentials of aqueous, methanolic and ethyl acetate fractions of argan and olive leaves of different antioxidant models compared to standard antioxidants

\begin{tabular}{|c|c|c|c|c|c|c|}
\hline \multirow{3}{*}{ Sample } & \multicolumn{6}{|c|}{$\mathrm{IC}_{50}(\mathrm{mg} / \mathrm{ml})$} \\
\hline & \multicolumn{2}{|c|}{ FRAP } & \multicolumn{2}{|c|}{ DPPH } & \multicolumn{2}{|c|}{ ABTS } \\
\hline & Argan & Olive & Argan & Olive & Argan & Olive \\
\hline AQ & $1.647 \pm 0.007^{c}$ & $1.018 \pm 0.004^{b}$ & $0.823 \pm 0.004^{c}$ & $1.643 \pm 0.014^{\mathrm{c}}$ & $1.380 \pm 0.013^{\mathrm{b}}$ & $3.342 \pm 0.006^{\mathrm{c}}$ \\
\hline $\mathrm{ME}$ & $0.420 \pm 0.001^{b}$ & $1.380 \pm 0.002^{c}$ & $0.212 \pm 0.001^{b}$ & $1.380 \pm 0.005^{b}$ & $2.120 \pm 0.002^{\mathrm{c}}$ & $1.647 \pm 0.004^{b}$ \\
\hline EA & $1.880 \pm 0.003^{\mathrm{d}}$ & $1.720 \pm 0.001^{\mathrm{d}}$ & $0.940 \pm 0.003^{\mathrm{d}}$ & $1.725 \pm 0.004^{\mathrm{d}}$ & ND & ND \\
\hline BHT & \multicolumn{4}{|c|}{$0.110 \pm 0.002^{\mathrm{a}}$} & \\
\hline Quercetin & \multicolumn{2}{|c|}{$0.033 \pm 0.006^{\mathrm{a}}$} & & & & \\
\hline Trolox & & & & & \multicolumn{2}{|c|}{$0.126 \pm 0.005^{\mathrm{a}}$} \\
\hline
\end{tabular}

Results are expressed as mean $\pm \mathrm{SD}(\mathrm{n}=3)$. ND - undetectable, AQ - aqueous, ME - methanolic, EA - ethyl acetate, BHT butylated hydroxytoluene antioxidant. Values in the column followed by a different letter superscript (a-d) are significantly different $(p<0.05)$. 
by aqueous argan $(59.92 \%)$ and olive $(26.27 \%)$ ones. The lowest $\beta$-carotene bleaching was detected for ethyl acetate argan $(16.88 \%)$ and olive $(9.84 \%)$ leaf fractions.

\section{Correlations between phenolic compounds and antioxidant activities}

Pearson's correlation coefficients between the total phenolic and flavonoid contents and their antioxidant capacities were determined to find their contribution to the antioxidant capacity of the analysed samples. The results indicated that TPC and TFC positively correlated with TAC and $\beta$-carotene bleaching inhibition and negatively with FRAP and DPPH assays (Table 3). However, significant correlations were found only between TFC and FRAP, $\mathrm{TAC}$ and $\beta$-carotene inhibition assays.

Table 3. Pearson's correlation coefficients between total phenolic content (TPC), total flavonoid content (TFC) and the different antioxidant methods used

\begin{tabular}{|l|c|c|c|c|c|}
\hline Variables & FRAP & DPPH & ABTS & TAC & $\beta$-carotene \\
\hline TPC & -0.63 & -0.57 & -0.08 & 0.72 & 0.69 \\
\hline TFC & $-0.86^{*}$ & -0.79 & -0.16 & $0.96^{* *}$ & $0.87^{*}$ \\
\hline
\end{tabular}

* significant at $p<0.05, * *$ significant at $p \leq 0.01$.

\section{DISCUSSION}

Based on biological and chemical mechanisms, different antioxidant activity assays have been reported to measure the antioxidant potential of plant materials (BAJPAI et al., 2005; BADAMI et al., 2007). Consequently, the reaction mechanisms of the antioxidant compounds are closely related to the reactivity and chemical structure of the free radicals as well as the environment in which these reactive species are found (Francenia Santos-Sánchez et al., 2019). Their functional mechanism relies on radicals deactivation by two significant mechanisms, which are the HAT (hydrogen atom transfer) and the SET (single electron transfer) reactions; or they may occur in parallel (Wright et al., 2001). Therefore, it is generally recommended to use more than one method to determinate antioxidant power of samples. Because their free radicals have different trapping capacities, where each chelating technique is specific for a very determined type of radical, and which can also contribute to the confirmation of the validity of results.
Phenolic compounds are bioactive secondary metabolites that are ubiquitously present in plants and plant products reported to be active as antioxidants (Cheynier, 2012).Their demodulation with chemical samples causes the reduction of reactive molecules into more stable ones by several potential pathways (BADAMI \& Channabasavaraj, 2007). Other studies have agreed in the beneficial and protective health effects of phenolic compounds in biological systems due to their capacity to transfer electron free radicals, chelate metal catalysts (FERRALI et al., 1997), activate antioxidant enzymes, reduce alpha-tocopherol radicals, and inhibit oxidases (Cos et al., 1998; НеIM et al., 2002). Since the antioxidant compounds found in plants have different polarities, different solvents have been used to isolate antioxidants (GoNG et al., 2012). In the fractionated extraction, it is quite essential to use different extraction solvents for a single sample to maximise the number of analysed fractions targeting further compounds or compound classes (SALEM et al., 2017). In the present study, the fractionation was selective according to the polarity of the solvent, and it was performed by Soxhlet extractor to obtain leaf fractions rich in varied phenolic nature precursors. This extractor apparatus was later adapted for the extraction of multiple polar compounds (AzmIR et al., 2013) despite that it has initially been conducted for lipid extraction using solvents such as hexane or petroleum ether (SOXHLET, 1879). Phenolic compound and flavonoid extractions from herbal plants are suitably performed with polar protic solvents such as water, methanol, ethanol, and polar aprotic solvents most frequently the ethyl acetate and the dichloromethane (AmRUthrAJ et al., 2012). In our case, we used polar protic and aprotic solvents in favour to trap hydrosoluble precursors of fatty acid synthesis with antioxidant potential, necessary during the ripening (maturation) process of the fruit. The bioactivity of natural compounds present in argan and olive leaves are of great interest as powerful protective agents (EL AdiB et al., 2015; Oughilas et al., 2018; Vogel et al., 2015). Their phytochemical characterisation has identified interesting phytoconstituents. Two major flavonols (myricetin and quercetin) and their glycoside derivatives are the most abundant in argan leaf extract determined as myrecitin-3-galactoside, myrecitin-3-gluctoside, myrecitin-3-xyloside, quercetin-3-galactoside, quercetin-3-glucoside, 
quercetin-3-arabinofuranoside, quercetin-3-rhamnoside, and hyperoside (TAHrouch et al., 2000; DAKICHE et al., 2016). While in olive case, they are described as oleuropein, luteolin 7-O-glucoside, apigenin 7-Oglucoside, luteolin 4'-O-glucoside, verbascoside, rutin, and caffeic acid (PEREIRA et al., 2007).

Recent evaluations of argan and olive leave phenolic compounds and their antioxidant activities have revealed huge diversity of the results. For argan leaves, the phenolic compounds content varies from 29.91 to $447.22 \mathrm{mg} \mathrm{GAE} / \mathrm{g} \mathrm{DW}$; similarly, the flavonoids content shifts from 1.18 to $185.93 \mathrm{mg}$ QE/g DW (FAHMi et al., 2013; DJIDEL et al., 2014; El AdIB et al., 2015; DaKiche et al., 2016; KecheBAR et al., 2017) under the influence of the extraction technique, the genotype and harvesting period variety as well as the impact of the geo-climatic conditions. For olive leaves, the phenolic compound content is in the range of 1.60 to $268 \mathrm{mg} \mathrm{GAE} / \mathrm{g}$ DW (HAYEs et al., 2011; MylonaKi et al., 2008; Ben Salah et al., 2012; KHALIQ et al., 2015; KulaK et al., 2016; Athanasiadis et al., 2017a, b; OrAK et al., 2019). In the same context, olive leaf flavonoid content shifts between 40.27 to $144 \mathrm{mg}$ QE/g DW (SKeRget et al., 2005; MAKRIS et al., 2007; KhaliQ et al., 2015; ÇETINKAYA \& Kulak, 2016) under the influence of the solvent type, the age of trees subjected to different water regimes, the multiple cultivars collected from separate locations and tree genotype factors. In turn, $\mathrm{IC}_{50}$ value is a sort of measure that indicates the effectiveness of a substance or a group of molecules in inhibiting a specific free radical type. The available literature of the studied leaves scavenging capacity has been reported to be largely varying among solvent type used for the extraction. DPPH $\mathrm{IC}_{50}$ values range, for argan, from 0.002 to $0.125 \mathrm{mg} / \mathrm{ml}$ (DJidel et al., 2014; Dakiche et al., 2016; KeCheBAR et al., 2017). Analogously, olive $\mathrm{IC}_{50}$ values for DPPH assay significantly vary between 0.007 and $0.970 \mathrm{mg} / \mathrm{ml}$ (ABAZA et al., 2011; Ben SAlah et al., 2012; Khaliq et al., 2015; OraK et al., 2019). FRAP $\mathrm{IC}_{50}$ values vary, for argan, from 0.239 to $0.330 \mathrm{mg} / \mathrm{ml}$ (KeCHEBAR et al., 2017) and from 0.007 to $0.018 \mathrm{mg} / \mathrm{ml}$ (ABAZA et al., 2011) in olive extracts. Further, the ABTS inhibition concentrations range from $0.005 \mathrm{mg} / \mathrm{ml}$ to $0.009 \mathrm{mg} / \mathrm{ml}$ in olive samples (DJiDEL et al., 2014).Compared to the previous studies, our results were in between of the qualitative and quantitative tests carried out. They showed that argan leaf total phenolic and flavonoid contents were greater than their contents in the olive leaves. It was revealed that in aqueous extracts, TPC and TFC were 1.5 times higher than those observed in olive samples. While methanolic extracts were more than two times richer in total phenolic and flavonoid compared to the olive samples. With a similar tendency, an increase of the extracts TPC/TFC means an increase of the scavenging potential, which led to a decrease of the $\mathrm{IC}_{50}$ values obtained. Most studied fractions presented a low $\mathrm{IC}_{50}$ value, which indicates a higher antiradical activity and confirms their good antioxidant potential. For both leaf species, the $\mathrm{ABTS}^{+}$radical scavenging activity of ethyl acetate fractions could not be determined due to their inhibition value of less than $50 \%$.

As it was revealed for the in vitro antioxidant power determinations, the chemical and molecular approaches of the assay should be taken into consideration by the reason of its impact on the mechanism and kinetics of antioxidants such as the influence of the structure of the antioxidant molecule (LÜ et al., 2009) and the $\mathrm{pH}$ of the assay solution on the antioxidants reactivity (AMORATI et al., 2006; ABRAMOVIČ et al., 2018). Notably, the large antioxidant potential variability noticed among species has been scientifically explained by its dependency on many factors such as the biological restrictions (genotype, organ and ontogeny) (Alfaro et al., 2013), the environmental stresses (temperature, salinity, water stress and light intensity) (FAHMI et al., 2011; KeCHEBAR et al., 2017), geographic origin and harvesting date (Al-RIMAWI et al., 2014), agronomic techniques (irrigation, fertilisation) (MACHADO et al., 2013) as well as the experimental conditions (storage, extraction technique and thermal processing) (Ksouri et al., 2008; Aouidi \& Hamdi, 2016). Indeed, the solvent polarity level and their accordance with the species nature appeared to be playing a significant role in secondary metabolites extraction.

\section{CONCLUSION}

The present work was the subject of a comparative study between argan and olive leaf antioxidant activity under the same experimental conditions. In vitro antioxidant activity estimation showed that both plant leaves had significant antioxidant potential. The 
antioxidant capacity of argan leaves was found to be significantly higher than that of olive leaves. The different analysed extract fractions of both species revealed the presence of high content of phenolic compounds responsible for the observed antioxidant activities. Argan and olive leaves can be considered as having significant antioxidant potential, expanding their ability to replace synthetic antioxidants in the food industry.

\section{ACKNOWLEDGEMENTS}

The authors thank the University of Sidi Mohamed Ben Abdellah, Fez, Morocco, for supporting this study.

\section{REFERENCES}

Abaza L., Ben Youssef N., Haddada F.M., MethenNi K., Zarrouk M., 2011: Chétoui olive leaf extracts: influence of the solvent type on phenolics and antioxidant activities. - Grasas y Aceites, 62(1): 96-104.

Abramovič H., Grobin B., Poklar Ulrih N., Cigić B., 2018: Relevance and standardization of in vitro antioxidant assays: ABTS, DPPH, and Folin-Ciocalteu. - Journal of Chemistry, 2018: 1-9.

Alfadda A.A., Sallam R.M., 2012: Reactive oxygen species in health and disease. - Journal of Biomedicine and Biotechnology, 2012: 1-14.

Alfaro S., Mutis A., Palma R., Quiroz A., Seguel I., Scheuermann E., 2013: Influence of genotype and harvest year on polyphenol content and antioxidant activity in murtilla (Ugni molinae Turcz) fruit. - Journal of Soil Science and Plant Nutrition, 13(1): 67-78.

Al-rimawi F., Odeh I., Bisher A., Abbadi J., QabbaJEH M., 2014: Effect of geographical region and harvesting date on antioxidant activity, phenolic and flavonoid content of olive leaves. - Journal of Food and Nutrition Research, 2(12): 925-930.

Amorati R., Pedulli G.F., Cabrini L., Zambonin L., LANDi L., 2006: Solvent and $\mathrm{pH}$ effects on the antioxidant activity of caffeic and other phenolic acids. - Journal of Agricultural and Food Chemistry, 54(8): 2932-2937.

Amruthraj N.J., Raj-Preetam J.P., Saravanan S., Lebel-Antoine L., 2014: Impact of organic sol- vents in the extraction efficiency of therapeutic analogue capsaicin from Capsicum chinense Bhut Jolokia Fruits. - International Journal of Pharmaceutical and Clinical Research, 6(2): 159-164.

Aouidi F., HAmdi M., 2016: Antioxidant capacity and phenolic content in olive leaf tisane as affected by boiling treatment. - PhytoChem \& BioSub Journal, 10(2): 39-50.

Athanasiadis V., Grigorakis S., Lalas S., MaKRIS P.D., 2017a: Highly efficient extraction of antioxidant polyphenols from Olea europaea leaves using an eco-friendly glycerol/glycine deep eutectic solvent. - Waste Biomass Valorization, 9(11): 1985-1992.

Athanasiadis V., Grigorakis S., Lalas S., MaKRIS P.D., 2017b: Methyl $\beta$-cyclodextrin as a booster for the extraction for Olea europaea leaf polyphenols with a bio-based deep eutectic solvent. - Biomass Conversion and Biorefinery, 8(2): 345-355.

Athar M., 2002: Oxidative stress and experimental carcinogenesis. - Journal of Biomedicine and Biotechnology, 40(6): 656-667.

Azmir J., Zaidul I.S.M., Rahman M.M., Sharif K.M., Mohamed A., Sahena F., Jahurul M.H.K., GhafOOR K., Norulaini N.A.N., OMar A.K.M., 2013: Techniques for extraction of bioactive compounds from plant materials: a review. - Journal of Food Engineering, 117(4): 426-436.

Badami S., Channabasavaraj K.P., 2007: In vitro. Antioxidant activity of thirteen medicinal plants of India's Western Ghats. - Pharmaceutical Biology, 45(5): 392-396.

Bajpai M., Pande A., Tewari S.K., Prakash D., 2005: Phenolic contents and antioxidant activity of some food and medicinal plants. - International Journal of Food Sciences and Nutrition, 56(4): 287-291.

Ben Salah M., Abdelmelek H., Abderraba M., 2012: Study of phenolic composition and biological activities assessment of olive leaves from different varieties grown in Tunisia. - Medicinal Chemistry, 2(5): 107-111.

Besnard G., Henry P., Wille L., Cooke D., ChaPUIS D., 2007: On the origin of the invasive olives (Olea europaea L., Oleaceae). - Heredity, 99(6): 608-619.

Bisignano G., Tomaino A., Lo Cascio R., Crisafi G., 
Uccella N., SAija A., 1999: On the in-vitro antimicrobial activity of oleuropein and hydroxytyrosol. - Journal of Pharmacy and Pharmacology, 51(8): 971-974.

Burits M., Bucar F., 2000: Antioxidant activity of Nigella sativa essential oil. - Phytotherapy Research, 14(5): 323-328.

Çetinkaya H., Kulak M., 2016: Relationship between total phenolic, total flavonoid and oleuropein in different aged olive (Olea europaea L.) Cultivar leaves. - African Journal of Traditional, Complementary and Alternative Medicines, 13(2): 81-85.

Charrouf Z., Guillaume D., 2007: Phenols and polyphenols from Argania spinosa. - American Journal of Food Technology, 2(7): 679-683.

Cheynier V., 2012: Phenolic compounds: from plants to foods. - Phytochemistry Reviews, 11(2-3): 153-177.

Cos P., Ying L., Calomme M., Hu J.P., Cimanga K., Van Poel B., Pieters L., Vlietnck A.J., Vanden BERGHE D., 1998: Structure-activity relationship and classification of flavonoids as inhibitors of xanthine oxidase and superoxide scavengers. Journal of Natural Products, 61(1): 71-76.

Dakiche H., Khali M., Abu-el-haija A.K., Al-MaayTAH A., Al-Balas Q.A., 2016: Biological activities and phenolic contents of Argania spinosa L. (Sapotaceae) leaf extract. - Tropical Journal of Pharmaceutical Research, 15(12): 2563-2570.

Dueridane A., Yousfi M., Nadjemi B., BoutassouNA D., Stocker P., Vidal N., 2006: Antioxidant activity of some Algerian medicinal plants extracts containing phenolic compounds. - Food Chemistry, 97(4): 654-660.

Duidel S., Chater C.F., Khennouf S., Baghiani A., Harzallah D., 2014: Evaluation of phenolic compounds, flavonoids and antioxidant properties of Argania spinosa (L.) Skeels leaf extracts. - Global Journal of Research on Medicinal Plants and Indigenous Medicine, 3(11): 416-426.

El Adib S., Aissi O., Charrouf Z., Ben Jeddi F., Messaoud C., 2015: Argania spinosa var. mutica and var. apiculata: variation of fatty-acid composition, phenolic content, and antioxidant and $\alpha$-amylase inhibitory activities among varieties, organs, and development stages. - Chemistry \& Biodiversity, 12(9): 1322-1338.
El Aich A., El Assouli N., Fathi A., Morand-feHR P., Bourbouze A., 2007: Ingestive behaviour of goats grazing in the Southwestern Argan (Argania spinosa) forest of Morocco. - Small Ruminant Research, 70(2-3): 248-256.

Fahmi F., Tahrouch S., Bouzoubâa Z., Hatimi A., 2011: Effet de l'aridite sur la biochimie et la physiologie d'Argania spinosa. - In: Congrès International de l'Arganier, Actes du Premier Edition: 299-308. - Agadir.

Fanmi F., Tahrouch S., Hatimi A., 2013: Geoclimatic influences on flavonoids contents of the leaves of the argan tree. - Journal of Materials and Environmental Science, 4(6): 881-886.

Ferrali M., Signorini C., Caciotti B., Sugherini L., Ciccoli L., Giachetti D., Comporti M., 1997: Protection against oxidative damage of erythrocyte membranes by the flavonoid quercetin and its relation to iron chelating activity. - FEBS Letters, 416(2): 123-129.

Francenia Santos-Sánchez N., Salas-Coronado R., Villanueva-Cañongo C., Hernández-Carlos B., 2019: Antioxidants. - In: Shalaby E. (ed.), Antioxidant compounds and their antioxidant mechanism: 1-28. - Rijeka.

Gong Y., Liu X., He W.H., Xu H.G., Yuan F., GAO Y.X., 2012: Investigation into the antioxidant activity and chemical composition of alcoholic extracts from defatted marigold (Tagetes erecta L.) residue. - Fitoterapia, 83(3): 481-489.

Gullón B., Gullón P., Eibes G., Cara C., De Torres A., López-Linares J.C., Ruiz E., Castro E., 2018: Valorisation of olive agro-industrial byproducts as a source of bioactive compounds. Science of the Total Environment, 645: 533-542.

Hayes J.E., Allen P., Brunton N., Grady M.N.O., Kerry J.P., 2011: Phenolic composition and in vitro antioxidant capacity of four commercial phytochemical products: Olive leaf extract (Olea europaea L.), lutein, sesamol and ellagic acid. Food Chemistry, 126(3): 948-955.

Heim K.E., Tagliaferro A.R., Bobilya D.J., 2002: Flavonoid antioxidants: chemistry, metabolism and structure-activity relationships. - Journal of Nutritional Biochemistry, 13(10): 572-584.

Kechebar M.S.A., Karoune S., Falleh H., BelhamRa M., Rahmoune C., Ksouri R., 2017: LC-MS phenolic composition changes and antioxidant 
capacities of the Saharan tree Argania spinosa leaves under salinity. - Courrier du Savoir, 23: 29-38.

Khaliq A., Sabir S.M., Ahmad S.D., Boligon A.A., Linde Athayde M., Jabbar A., Qamar I., Khan A., 2015: Antioxidant activities and phenolic composition of Olive (Olea europaea) leaves. - Journal of Applied Botany and Food Quality, 88: 16-21.

Ksouri R., Megdiche W., Falleh H., Trabelsi N., Boulaaba M., Smaoui A., Abdelly C., 2008: Influence of biological, environmental and technical factors on phenolic content and antioxidant activities of Tunisian halophytes. - Comptes Rendus Biologies, 331(11): 865-873.

LÜ J.M., LIN P.H., Yao Q., Chen C., 2009: Chemical and molecular mechanisms of antioxidants: experimental approaches and model systems. Journal of Cellular and Molecular Medicine, 14(4): 840-860.

Machado M., Felizardo C., Fernandes-Silva A.A., Nunes F.M., Barros A., 2013: Polyphenolic compounds, antioxidant activity and 1-phenylalanine ammonia-lyase activity during ripening of olive cv. 'Cobrançosa' under different irrigation regimes. - Food Research International, 51(1): 412-421.

Makris D.P., Boskou G., Andrikopoulos N.K., 2007: Polyphenolic content and in vitro antioxidant characteristics of the wine industry and other agri-food solid waste extracts. - Journal of Food Composition and Analysis, 20(2): 125-132.

Myasnikov V.Y., Ivanov E.V., Sakanyan E.I., 2010: Determining the kinetic characteristics of plant raw material extraction by repercolation. - Pharmaceutical Chemistry Journal, 44(4): 202-204.

Mylonaki S., Kiassos E., Makris D.P., Kefalas P., 2008: Optimisation of the extraction of olive (Olea europaea) leaf phenolics using water/ ethanol-based solvent systems and response surface methodology. - Analytical and Bioanalytical Chemistry, 392(5): 977-985.

Orak H.H., Karamac M., Amarowicz R., Orak A., PenKacik K., 2019: Genotype-related differences in the phenolic compound profile and antioxidant activity of extracts from olive (Olea europaea L.) leaves. - Molecules, 24(6): 1130-1144.

Oughilas A., Cheriti A., Berbaoui H., Reddy K.H., Govender P., 2018: Phytochemical screening and antibacterial activity of leaves extracts from the endemic Argania spinosa (L.) Skeels from Tindouf (Algerian Sahara). - PhytoChem \& BioSub Journal, 12(1): 67-71.

Oyaizu M., 1986: Studies on products of browning reactions: Antioxidative activities of product of browning reaction prepared from glucosamine. Japan Journal of Nutrition and Dietetics, 44(6): 307-315.

Ozsoy N., Can A., Yanardag R., Akev N., 2008: Antioxidant activity of Smilax excelsa L. leaf extracts. - Food Chemistry, 110(3): 571-583.

Pennington T.D., 1991: The genera of Sapotaceae. London.

Pereira A.P., Ferreira I.C.F.R., Marcelino F., Valentão P., Andrade P.B., Seabra R., Estevinho L., Bento A., Pereira J.A., 2007: Phenolic compounds and antimicrobial activity of olive (Olea europaea L. Cv. Cobrançosa) leaves. Molecules, 12(5): 1153-1162.

Prieto P., Pineda M., Agullar M., 1999: Spectrophotometric quantitation of antioxidant capacity through the formation of a phosphomolybdenum complex: Specific application to the determination of Vitamine E. - Analytical Biochemistry, 269(2): 337-341.

Re R., Pellegrini N., Proteggente A., Pannala A., Yang M., Rice-Evans C., 1999: Antioxidant activity applying an improved ABTS radical cation decolorization assay. - Free Radical Biology and Medicine, 26(9-10): 1231-1237.

Salem M., Bernach M., Bajdzienko K., GiavalisCO P., 2017: A simple fractionated extraction method for the comprehensive analysis of metabolites, lipids, and proteins from a single sample. Journal of Visualized Experiments, 124: 1-10.

Shi S., Guo K., Tong R., Liu Y., Tong C., Peng M., 2019: Online extraction-HPLC-FRAP system for direct identification of antioxidants from solid Du-zhong brick tea. - Food Chemistry, 288: 215-220.

Skerget M., Kotnik P., Hadolin M., Rizner Hras A., Simonic M., KNeZ Z., 2005: Phenols, proanthocyanidins, flavones and flavonols in some plant materials and their antioxidant activities. - Food Chemistry, 89(2): 191-198.

Slinkard K., Singleton V.L., 1977: Total phenol analysis: Automation and comparison with man- 
ual methods. - American Journal of Enology and Viticulture, 28(1): 49-55.

Souilem S., Fki I., Kobayashi I., Khalid N., Neves M., Isoda H., SAYadi S., Nakajima M., 2017: Emerging technologies for recovery of value-added components from olive leaves and their applications in food/feed industries. - Food and Bioprocess Technology, 10(2): 229-248.

Soxhlet F., 1879: Die gewichtsanalytische bestimmung des milchfettes. - Dingler's Polytechnisches Journal, 232: 461-465.

Spinelli R., Picchi G., 2010: Industrial harvesting of olive tree pruning residue for energy biomass. Bioresource Technology, 101(2): 730-735.

Tahrouch S., Andary C., Rapior S., Mondolot L., Gargadennec A., Fruchier A., 2000: Polyphenol investigation of Argania spinosa (Sapotaceae) endemic tree from Morocco. - Acta Botanica Gallica, 147(3): 225-232.

Tair A., Weiss E.K., Palade L.M., Loupassaki S.,
Makris D.P., IoAnnou E., Roussis V., Kefalas P., 2014: Origanum species native to the island of Crete: In vitro antioxidant characteristics and liquid chromatography-mass spectrometry identification of major polyphenolic components. Natural Product Research, 28(16): 1284-1287.

Vogel P., Machado I.K., Garavaglia J., Zani V.T., De Souza D., Morelo Dal Bosco S., 2015: Polyphenols benefits of olive leaf (Olea europaea L) to human health. - Nutrición Hospitalaria, 31(3): 1427-1433.

Wootton-Beard P.C., Ryan L., 2011: A beetroot juice shot is a significant and convenient source of bioaccessible antioxidants. - Journal of Functional Foods, 3(2): 329-334.

Wright J.S., Johnson E.R., Dilabio G.A., 2001: Predicting the activity of phenolic antioxidants: Theoretical method, analysis of substituent effects, and application to major families of antioxidants. - Journal of the American Chemical Society, 123(6): 1173-1183.

\section{ARGANIA SPINOSA IR OLEA EUROPAEA LAPŲ FENOLINIŲ JUNGINIŲ IR ANTIOKSI- DANTINIO AKTYVUMO PALYGINIMAS}

\section{Aziza Lfitat, Hind ZeJui, Abdelkamel Bousselham, Yassine El Atki, Badiaa Lyoussi, Abdelka- der Gourch, Abdelfattah Abdellaoui}

\section{Santrauka}

Šis tyrimas buvo atliktas siekiant nustatyti ir palyginti bendrą fenolinių junginių ir flavonoidų kieki argano ir alyvuogių lapuose, o taip pat jų antioksidacines savybes vandeniniuose, metanoliniuose ir etilo acetato ekstraktuotose. Antioksidantinès ekstraktu savybès buvo įvertintos in vitro, naudojant DPPH•, ABTS radikalų surišimo gebos, geležies redukcijos galios bei bendro antioksidantų gebejjimo slopinanti $\beta$-karotino / linolio rūgšties emulsijos peroksidaciją metodus. Nustatytas bendras fenolinių junginių kiekis, išreikštas galo rūgšties ekvivalentu argano lapų ekstraktuotose kito nuo 221,69 $\pm 2,07$ iki 1,32 $\pm 0,01 \mathrm{mg} / \mathrm{g}$ sausos masès (MS), o alyvuogių ekstraktuotose - nuo 144,61 $\pm 0,82 \mathrm{iki} 1,21 \pm 0,02 \mathrm{mg} / \mathrm{g}$ MS. Bendras flavonoidų kiekis, išreikštas kvercetino ekvivalentu, argano méginiuose įvairavo nuo 267,37 $\pm 1,12$ iki $25,48 \pm 0,02 \mathrm{mg} / \mathrm{g}$ MS, o alyvuogiu lapuose - nuo 96,06 $\pm 0,78$ iki 10,63 $\pm 0,05 \mathrm{mg} / \mathrm{g}$ MS. Tyrimas parodè, kad argano ir alyvuogių lapuose nustatyti plifenoliniai junginiai pasižymi didele laisvujų radikalų surišimo geba. Argano lapų ekstraktų antioksidantinès savybès stipresnès nei alyvmedžiu lapų. Tirtos lapų žaliavos yra natūralių antioksidantų šaltiniai. 